\title{
Research on the Cultivation Mode of College Students' Humanistic Information Literacy
}

\author{
Xin $\mathrm{Li}^{1, \mathrm{a}}$ and Bo Guan ${ }^{1, \mathrm{~b}^{*}}$ \\ ${ }^{1}$ Library, Beihua University, Jilin, China \\ ${ }^{2}$ Public Language Institute, Beihua University, Jilin, China \\ alixin198282@163.com, b304230443@qq.com \\ * Corresponding author
}

Keywords: Classical literature; Humanistic quality; Training mode; Information literacy

\begin{abstract}
In the information society, the abundance of material and information does not improve the humanistic quality and comprehensive information literacy of College students. Although college students have a high level of education, they generally show a low level of humanistic quality. Through exploring the humanistic spirit of classical literature, this paper aims to improve the level of information literacy education of college students through reading and popularizing classical literature.
\end{abstract}

\section{Introduction}

With the development of the information society, the network is ubiquitous, and there are many ways for people to acquire knowledge and information [1]. The authenticity of a large number of network information is not understood. Because of the subjective difference of user's cognitive behavior, it is difficult for users to find the information they need in the process of retrieval. The ability to distinguish information from reality, to acquire correct knowledge and to improve individual self-study ability is a realistic problem to improve the information literacy education of contemporary college students.

In recent years, with the rapid development of modern technology and market economy, people's living standards continue to improve, but in addition to the great wealth of material, spiritual and moral people gap increasing, people enjoy the network modernization brings convenient life while also trying to seek spiritual comfort. The fierce competition in the information society, people can get a lot of information resources through the intelligent equipment diversification, information retrieval and search ability of great progress, but the information retrieval results have serious quality problems [2]. Although the college students have a high level of education, because of the erosion of various ideological trends in society and the negative adverse effects, the phenomenon of humanistic quality is generally low. Some students have incorrect values, individualism and hedonism, lack of social ethics and sense of responsibility [3].

The 21st century, the reform of education has paid more attention to training students' information literacy education, especially the comprehensive ability of highly qualified personnel. The university library is the information resource center of school, the important content of the university education reform, strengthens the information literacy level of the university student, trains the high-quality and innovative talented person who is suitable for the information society [4]. But the cultivation of information literacy level for university students mainly include the humanities, scientific literacy, arts literacy and social skills and other aspects of education. Humanistic quality is the most basic quality in the whole quality level. It is the primary and core factor to improve the whole level of the university students' information literacy, and has great influence on the shaping of personality and the formation of other qualities [5]. Therefore, analysis the cultivation of humanistic quality education in the role college students' quality level, through the combination of general education and the ways and means to carry out special education, promotion of reading classical literature, to enhance the humanistic quality of the college students, and to cultivate and shape the high qualified and innovative talents to meet the needs of the information 
society. Through the promotion of classical literature reading, thematic education and general education are combined to enhance the humanistic quality of college students and to cultivate high-quality and innovative talents to meet the needs of the information society.

\section{Survey of Humanistic Quality of Contemporary College Students}

College students have a high level of cultural quality, but because of the complexity of the network information, there is a lack of humanistic quality. Through the research methods of questionnaires, this paper designs questions about humanistic quality and information retrieval literacy, such as 20 channels. The questionnaires were issued to the students in the library, including the students and graduate students. 100 questionnaires were issued and 94 questionnaires were withdrawn. This questionnaire survey was completed by means of quantitative statistics and quantitative methods. Specific test results are shown in Table 1.

Table 1 Statistical results of some survey tests

\begin{tabular}{|c|l|c|c|}
\hline Number & \multicolumn{1}{|c|}{ Survey Content } & Statistics & Weight \\
\hline 1 & $\begin{array}{l}\text { The information source is the classic bibliography } \\
\text { for searching information. }\end{array}$ & 22 & $23.4 \%$ \\
\hline 2 & Reading time more than three hours a day. & 15 & $16 \%$ \\
\hline 3 & $\begin{array}{l}\text { Reading classic books is important for improving } \\
\text { your humanities. }\end{array}$ & 26 & $27.7 \%$ \\
\hline
\end{tabular}

Statistics show that the number of people who read the classics is only $23.4 \%$, less than $1 / 3$ of the survey population, and college students do not realize the importance of reading classical books to enhance their humanistic quality.

\section{Cultivation Model of College Students' Quality Education Based on Humanistic Quality}

Classic literature is the treasure of civilization and the inheritance of history. Through reading classical ancient literature, college students can stand on the shoulders of their predecessors. They can increase their humanistic knowledge and enhance their own humanistic quality, which is the spiritual source for college students to achieve innovative talents.

Building a Reading Room for Literature and Creating an Atmosphere for Reading Classics. The library is the information resource and knowledge service center of the University, and it has a large collection of literature resources. In view of the benefits of reading classical literature, in order to cultivate the humanistic quality of college students, the library can build a specific and professional subject reading environment. To collect the books, literature, history, philosophy and other humanities library resources, and reasonable placement in relatively independent reading space, to provide readers with a professional museum of literature and history.

Select Classic Literature and Promote Classical Reading. As the Guarantee Center of literature resources, library shoulders the knowledge, information service and accomplishment education and training service of university. University Libraries give full play to the advantages of resources, discover and tap information, and improve the humanistic quality and information literacy education of College students. In the collection of paper resources and modern electronic resources, looking for classical Chinese bibliography, with profound educational significance of the traditional classics, can stimulate the humanistic spirit, and enhance the humanistic quality of College students. For example, the ancient classical fairy tales, through the heroic deeds of ordinary people, extol the objective and fearless spirit of people in the face of difficulties and setbacks. To educate students in the face of growing ups and downs, it is necessary to be brave, to cultivate lofty, firm consciousness and belief, and to improve self - cultivation.

Create Wonderful Activities to Improve Student Participation. The library regularly organizes special types of literature reading and promotion activities every year. For example, in 
commemoration of Confucius's birthday, through the heritage of Chinese classics, reading contests and other diverse classical literature and reading activities. Wonderful activities have been carried out to attract the enthusiasm of College students. These activities enrich the students' campus cultural life and improve their professional practice ability. At the same time, the introduction of classical literature, reading and other performing art elements has added to the aesthetics of classical literature, attracting more students' reading enthusiasm, and improving the reading participation of College students. The promotion of classic reading is consistent with the current government's call for universal reading.

Conduct Special Lectures to Cultivate Interest in Reading. In order to improve the overall literacy of students, the library usually carries out general education and quality improvement training for all students through public elective courses. The courses offered by public optional courses have advantages in improving the quality of College students. However, based on the disadvantages of general education, it is not a popular model for college students. Therefore, it is necessary to carry out special lectures for the purpose of improving the readers' information literacy level, according to the interest of the students in different majors. Through the micro lecture, we can arouse the interest and participation of college students, and avoid the forced learning model in which the students choose the courses in order to get all the credits. So as to improve students' willingness to read actively, to cultivate students' love of classic literature, and to stimulate their interest in reading.

Create a Scholarly Campus to Enhance the Quality of Humanity. With the development of the national reading craze, the reading enthusiasm of college students is gradually heating up. As an information service and resource construction department for reading promotion, libraries should adapt themselves to the trend of reading, collect catalogues, advocate reading, and create a reading environment within the whole school. In densely populated areas, such as the entrance to the dining hall, self-help books, books or machines, or the proper areas of students' teaching buildings and dormitories, are opened for leisure reading. Make students deeply feel the classic charm of literary culture and campus culture, and enhance their humanistic quality and information literacy in the process of imperceptible influence.

\section{Summary}

Ancient literary classics are the important carrier of Chinese traditional culture, including the profound and traditional cultural spirit, and the crystallization of the wisdom of their predecessors [6]. It was extended to the next generation, contain a wealth of humanistic spirit, including the spirit of unremitting self-improvement spirit and indomitable optimism in the face of failure. The excellent virtues and spirits of the Chinese nation have many advantageous in improving the quality education of College students. College students read classic ancient literature, learn the wisdom and follow the sages, It can increase its humanistic knowledge, cultivate its humanistic spirit, and improve its humanistic quality. It is also the spiritual source for college students to achieve innovative talents.

\section{Acknowledgements}

This paper is the relevant research result of the Educational Science Program in Jilin Province " Research on the teaching model reform of Library Literature Retrieval Course under the prosperity of network culture"(project number: GH170053); This paper is the relevant research result of the Teaching and research project of Beihua University (project number: XJQN2017011).

\section{References}

[1] S.S Xu: Information Research, (2017)No.7,P.84-87. (In Chinese) 
[2] Z.L Luo: Journal of Zhejiang University of Media \& Communications, Vol:22 (2015)No. 5,p.112-118.(In Chinese)

[3] F. Fu: Library Work and Study, (2015)No.6,p.89-93. (In Chinese)

[4] J.C Li: Journal of Library and Information Science, Vol:24(2014)No.14,p.75-77. (In Chi nese)

[5] M.Y Qin and X.X Zhuang: Journal of Academic Library and Information Science, Vol: 31(2013)No.5,p.77-80. (In Chinese)

[6] H.Y Li: Journal of Hengshui University, Vol: 11(2009)No.2,p.124-126. (In Chinese) 